\title{
Borders on the old maps of Jizera Mountain
}

\begin{abstract}
Old maps, mainly from the period between 1890 and 1940, have been collected in the framework of the project "Old Maps of the Jizera Mountains". These maps provide us with a complex picture, mainly of tourism, in this currently Czech-Polish territory.

The territory of the Jizera Mountains was inhabited mainly by a Germanspeaking population on both sides of the border until 1945. Yet it is interesting to examine how the border between the two states - in those times Czechoslovakia and Germany, now Czechia and Poland - was illustrated on these old maps. This article argues that the border was not perceived as a barrier as such until later on, mainly due to the ethnic change in the borderlands. It also reveals that the borders on the maps are of manifold nature and cannot be simply limited to the national borders.
\end{abstract}

Keywords

Old maps • borders $\cdot$ German speaking population • geopolitics $\cdot$ Jizera Mountains

(C) University of Warsaw - Faculty of Geography and Regional Studies

\author{
Hynek Böhm ${ }^{1,2}$, Jiří Šmída² \\ ${ }^{1}$ Institute of Political Science, University of Opole \\ Poland \\ ${ }^{2}$ Faculty of Science, Humanities and Education, \\ Technical University of Liberec, Czech Republic \\ e-mail: hynek.bohm@tul.cz \\ e-mail: jiri.smida@tul.cz \\ Received: 30 November 2018 \\ Accepted: 28 May 2019
}

Introduction

The state border is a barrier that most people perceive and use to construct their identity vis-à-vis the neighbouring country (van Houtum 1999). However, boundaries and their depiction on maps can bear multiple forms: most of the time, we provide other administrative-political boundaries where states are divided into smaller units, such as regions, provinces, counties or districts. Some of these borders have survived since their creation to the present, others serve as memory (see Jańczak's concept of the phantom border, 2014). In our article, we focus on the territory of the Jizera Mountains which is currently shared by Czechia and Poland.

The main objective of this article is thus to analyze the depiction of borders on old maps from the beginning of the 20th century in the light of Martinez's (1994) approach to the typology of borders. As we have been working with old tourist maps, we also focus on elements of tourist infrastructure and tourist routes crossing the border. The studied region currently comprises the Czech-Polish Jizera Mountains. However, the region was inhabited mainly by German-speaking populations on both sides of the border until 1945. Therefore, it is interesting to examine how the borders between neighbouring states, i.e. between the Austro-Hungarian Empire and Germany until 1918, and between Czechoslovakia and Germany until 1938 and for a short period after the Munich Agreement of 1938, were illustrated in these old maps. Another part of our research focus is to ascertain whether the depiction of borders on these old maps correlates with the changing functions of these borders.

In our paper, we also wish to verify whether Poser's (1939, in Kreisel 2004) definition of "tourist regions" as "special entities with a definite character that sets them apart from other regions" was applied in the old maps that we studied. Tourism, alongside other processes, creates distinctive regions, and in our context these are cross-border regions.

We have approached this topic knowing that its methodology and research goals could be questioned. However, we hope that our results will be solid enough to prove that research in this direction is not a dead end.

\section{Theoretical background}

In our paper, we are going to address issues of the geography of tourism and border studies. It is important to underline that Poser's (1939) study of tourism in the Giant mountains/Riesengebirge (Karkonosze/Krkonoše in Polish and Czech) is considered the first study to analyze the geography of tourism in a Central European (and German-speaking) context. Poser argued that tourism takes place in geographical space to create its own particular type of cultural landscape in the process (Kreisel 2004). The Riesengebirge/Giant Mountains had a very similar framework or context to the Jizera Mountains region which we studied, located just twenty-five kilometres westwards - it was also a German-speaking territory between Prussia (later Germany) and Austria (later Czechoslovakia).

\section{The meaning of borders and their functions}

Power is executed in concrete geographical and administrative units, which are defined by boundaries among other things, and are mostly expressed geographically. These boundaries draw differences and constitute barriers and have 
multiple meanings, be it psychological, mental or linguistic (Böhm 2019).

We will use a range of terms in the text, distinguishing between "boundary" and "frontier", based on Jańczak's (2014) explanation. In this framework, a boundary is mainly a legal concept which separates state structures (O'Dowd \& Wilson 2002). Boundaries then are "sharply drawn lines that mark the limits of authority and ownership (...), marked, and managed, sometimes loosely and sometimes strictly in accordance with the various and changing purposes of the adjoining states" (Custred 2011). A boundary not only separates what is outside, but at the same time binds what is inside (Kristof 1959). Boundarization refers to the creation of a state under the Westphalian order with a clearly defined space, authority and territorially circumscribed population. The process, initiated in Europe in the 17th century, became particularly evident during the nation-state building processes. Boundarization has been reflected on the maps by means of drawing borders as dividing lines.

Frontier is a broader term. It applies to social, economic and political elements referring chiefly to borderland communities (O'Dowd \& Wilson 2002). As a result, frontiers are "zones of varying width, either political or cultural in nature" (Custred 2011). Assimilation or even expansion by one of the dominating parties is becoming a common frontier occurrence (Walters 2004). Since the border is drawn in a way enabling interaction and contact between disparate systems, borderlands of new quality are emerging and they differ greatly from their interiors. Consequently, an opinion has been formed that a frontier is an antechamber to the territory proper (Kristof 1959)

The delegitimization and devaluation of borders are connected to the process of frontierization, as it prompts the erosion of boundaries. Limited border controls and the declining importance of borders lead to their increasing permeability (see, for example, Kolejka et al. 2015 or Stryjakiewicz 1998), to more intensive interaction, and consequently to the emergence or reconstruction of the elements of a frontier. We can say that European integration processes have largely contributed to the softening of the meaning of borders.

Nevertheless, at the same time, the two processes unfold in a context of historical legacy, as well as in actual border reality. Keeping in mind the historical origin of borders, both boundarization and frontierization reveal their dual nature. On the one hand, they reflect ongoing existing processes; therefore, they constitute an element of a real policy specific to a time and place. On the other hand, however, they are set in a historical context where until recently borders served a different purpose, had a different form and ran along different lines. In some cases, borders were politically and historically sensitive issues, due to territorial disputes or recently reclaimed sovereignty. As a result, borders are defined in two ways: first, as an element of current and real politics, and secondly, as an element of historical legacy (Jańczak 2014).

Brunet-Jailly (2005) emphasizes that "each border is unique and no taxonomy of border is conceptually feasible because there are too many types of borders". Nevertheless, many scholars have attempted to propose such a methodology. We will specifically mention the concept of Martinez (2004), but there are also many others.

Martinez (1994) suggested a border typology based upon the openness of borders and identified four main types. 1) Alienated borders rigidly divide two countries; border areas are militarized scenes of confrontation and conflict, transborder traffic is minimal and cooperation between the parties is virtually non-existent. Most land borders in the world, however, would qualify as 2) coexistent borders. Such borders are primarily for the filtering of transborder flows, while the parties maintain contact and cooperate when required to solve common problems. 3) Interdependent borders arise between countries that have achieved a high degree of political rapprochement and mutual trust and which have coordinated foreign policy: the visa regime is lifted, border areas are fully demilitarized, and intense cooperation between the authorities of both states at different levels has been developed, as well as business entities and NGOs. Finally, 4) integrated borders are completely open; cross-border agglomerations and regions with their own governments are created, regulating the most important spheres of activity (Kolosov 2015).

\section{Research methodology}

Our research is based on the analysis of old tourist maps coming from the 1890-1940 period which we studied, as these are what we mainly managed to collect. This analysis is conducted after an explanation of the historical, socio-cultural and political conditions of the researched area and period. We mainly worked with maps produced by German-speaking authors coming from the Jizera Mountains (also known as Jizerské hory, Isergebirge, Góry Izerskie).

We analyze the depiction of the borders on the old maps from the beginning of the 20th century ${ }^{1}$ in compliance with Martinez's border typology. We take a closer look at the way these old maps deal with the concept of borders as a boundary separating state structures (O'Dowd \& Wilson 2002). We also examine the boundary's role as separator from the outside and binder of the inside (Kristof 1959). We analyze whether these old maps really perceive boundaries as "sharply drawn lines that mark the limits of authority and ownership (...), marked, and managed, sometimes loosely and sometimes strictly in accordance with the various and changing purposes of the adjoining states" (Custred 2011).

We also try to sketch a comparison of the old maps and leading tourist routes across the borders with the existing state in 2019. We emphasize the verb "to sketch", as the core of the article focuses on the old maps. Yet we have decided to also include this element.

Working with old tourist maps has its limits, because of missing details, such as the dating of the maps, or of inaccuracies. The special problem of the Jizerské hory/lsergebirge/Góry Izerskie/Jizera Mountains is their close location to the more popular and more cartographically depicted Krkonoše/ Karkonosze/Riesengebirge/Giant Mountains, which made our work somewhat more complicated, as the Jizera Mountains often appear on these old maps like a "younger brother" or a "byproduct". Nevertheless, we believe that we can contribute to the field of border research using this new approach.

\section{A brief history of the borderline in the Jizera Mountains}

\section{Historical context}

Since the "Silesian Wars" in the mid 18th century, the borderline divided Bohemia (part of the Austrian monarchy) and Lower Silesia (part of the Prussian Kingdom, then part of unified Germany after 1871). This year of Germany's unification is the starting point for the outline of the historical background of the territory studied for the purpose of this paper.

A short outline of the historical, political and socio-cultural conditions in the Sudetes - borderlands alongside the mountain range dividing Czech historical territory from German neighbours - between 1871 and 1945 will help us present the territory studied and its national/minority issues. The Western Sudetes were inhabited predominantly by German-speaking inhabitants until 1945. The main integrating factor of the territory was the common language of border inhabitants (see, for example, Dołzbłasz \& Raczyk 2010 or Dołzbłasz 2017). On the current Czech side,

\footnotetext{
${ }^{1}$ The list is provided in the methodology and references section.
} 
they were more connected to Vienna, the centre of the Habsburg monarchy, until 1918, than to Berlin or Saxony, as was the case on the other side of the border. However, there was a Czechspeaking minority in the southern part of the Western Sudetes. Furthermore, the Czechoslovak national policy of 1918-1938 caused a small increase in the number of Czech-languagespeaking inhabitants in the Sudetes. After 1938 the Nazi policy caused a decrease in the Czech minority population, but not their eradication. Germans were forcibly displaced (almost completely) from new Czechoslovakia and new Poland after 1945, but this period is not analyzed in the paper.

On the current Czech side of the border, the cultural and economic resurgence of Czechs challenged the German predominance, and "Sudetendeutschtum" - which can be translated as self-identification as Sudetes German - can be traced back to the unanimous voting of Bohemia's German deputies at Frankfurt's parliament of 1848. The progressively greater availability of Czech-language schooling consolidated the Slavic-speaking middle classes. As a result, the territory - both physical and intellectual - which had previously been considered German was increasingly infiltrated, until it was annexed outright by the declaration of Czechoslovak Statehood on 28 October 1918 (Burcher 1996).

The gradual shift in the balance of domestic power was accompanied by bureaucratic conflicts related to language laws and derived from ideas of the historic rights of nations and other collectives: what the criteria for native-language schooling in a particular district should be, whether and how the human geography of the historic provinces should affect access to justice in one language or the other.

The German language was used as the principal communication tool and it was also the mother tongue of the vast majority of the population living in the studied region. This changed slightly in 1918, when Czechoslovakia was founded and Germans were the biggest national minority in this state, living mainly in the border areas of the Sudetes/Sudetenland. Immediately after World War I these German-speaking parts of Czechoslovakia refused to be part of this state and declared independence; however, the Czechoslovak authorities managed to gain control over the territory rather quickly and this state of affairs was then confirmed by the Versailles system. The coexistence of Czechs and Germans was afterwards relatively calm until the mid 1930s. The German minority was allowed to use their language and the language regime along the border did not change substantially. Therefore, many printed works, including maps, were also published in German, and distributed in interwar Czechoslovakia. Most of the authors of the maps depicting the territory of the Jizera Mountains were German speaking, which was also reflected in the dominance of the German language on these maps.

After 1945, everything changed: a new western Polish border on the Nysa/Neisse and the Odra/Oder was defined; the German-speaking population was expelled from both Poland and Czechoslovakia. A major population exchange occurred. We can thus say that the population is largely new on both the Polish and the Czech side of the territory since the second half of the 1940s.

On the current Polish side, World War II did not have devastating consequences until evacuation was organized by the German authorities during the first half of 1945 (Miszewska 1994). When the German front collapsed under Soviet pressure at the end of winter of that year, the area was spared heavy fighting and the infrastructure remained largely intact. However, Germans started to leave and, following the arrival of the Soviet Red Army and the Potsdam Treaty (which placed Silesia under Polish administration), all the remaining Germans were displaced $(300,000-400,000)$ unless they could prove their Polish origin or their participation in anti-Nazi activities. Other nationalities (including Austrian Germans) remained, but nevertheless the late 1940s was a period of great migratory upheaval which had a particularly radical impact on the Sudetes where only some five per cent of the present population can be regarded as indigenous (Czetwertyński-Sytnik et al. 2000).

On the Czech side of the border, there was a massive expulsion of German speakers. "Between the years 1945 and 1947 , this is what happened to twenty-nine out of every thirty German speakers who were on Czechoslovak soil at the end of the Second World War, held collectively guilty for the destruction of the first Czechoslovak Republic in 1938-39" (Burcher 1996).

\section{The development of tourism}

Modern infrastructure (roads and railways) on the Prussian (Czetwertyński-Sytnik et al. 2000) as well as on the Austrian side of the border contributed to the rise of the Prussian/German as well as the Austrian/Czech industrial economies. This encouraged the development of towns on both sides of the border, especially on the mountain rim (Walbrzych) and in the principal valleys (Jelenia Gora, Kamienna Gora and Liberec on the Austrian side).

The infrastructure development and rising living standards (Murgaš 2019) also brought tourists to the mountains and health and spa resorts (inter alia Cieplice Slaskie, Karpacz or Szklarska Poręba on the Prussian side and Hejnice on the Austrian side). A particular role was played here by the inhabitants of Berlin - whose population rose from 750,000 in 1870 to 2 million in 1910. Thanks to the relatively efficient train connections it was possible to get to Jelenia Gora in a few hours, which substantially contributed to the use of the Giant mountains/Riesengebirge as a leisure destination for Berliners (Potocki 2004). This boom was accompanied by the development of services accompanying tourism. Unions of (German-speaking) tourists operating on both sides of the border started to publish maps depicting the territory. These maps were in German and thanks to the openness of the borders due to the Dresdner Convention, involved elements from both sides of the border. The role of organizations promoting tourism was particularly important in the German environment, as there were plenty of them in the whole of Germany - their initial purpose was to improve the general physical condition of young men so they would be prepared for eventual military conflict, but tourism seemed to be rather an appropriate complementary tool (Potocki 2004).

The end of World War I and the appearance of Czechoslovakia brought substantial changes to the territory studied. The existing dominance of German-speaking tourist organizations cooperating on both sides of the border started to be distorted by the Czech element that was appearing. Tourist organizations operating on the German side of the border started to complain about a worsening level of cooperation with their counterparts on the other (Czechoslovak) side of the border, and blamed Czechoslovak authorities. Antagonism from the international relations level, strengthened after the Nazis gained power in Germany in 1933, had repercussions also in other sectors, including tourism. One of the causes for this antagonism can be also found in the process of the "nationalization" of elements of the tourist infrastructure on the Czech side of the border, where German-speaking owners or operators of mountain cottages were replaced by Czech ones, as the forested border mountain territory was nationalized after establishing Czechoslovakia in 1918 - and the previous owners were mostly German-speaking entrepreneurs/members of the aristocracy (Wójcik 2015). Also, border crossing for tourism became more difficult than it had been before World War I. These difficulties were of rather administrative nature, yet it had a distinctly tourismpreventing nature, and had roots in the fight against smuggling, the emancipation of the newly born Czechoslovak State and the 
MISCELLANEA GEOGRAPHICA - REGIONAL STUDIES ON DEVELOPMENT

Vol. 23 • No. 4 • 2019 • pp. 199-209 • ISSN: 2084-6118 • DOI: 10.2478/mgrsd-2019-0021

Table 1. Development of state organizations and languages used in the region

\begin{tabular}{|c|c|c|c|}
\hline Period & Borders between & Border-crossing regime & $\begin{array}{c}\text { Languages used on both sides of the } \\
\text { border }\end{array}$ \\
\hline $1871-1918$ & Austrian Empire - Germany & Free & Almost exclusively German \\
\hline $1918-1938$ & Czechoslovakia - Germany & Strictly controlled & $\begin{array}{c}\text { Predominantly German (with minor usage } \\
\text { of Czech on the Czechoslovak side) }\end{array}$ \\
\hline $1938-1945$ & $\begin{array}{c}\text { No borders (annexation of } \\
\text { Sudetenland by the Third } \\
\text { Reich) }\end{array}$ & $\begin{array}{c}\text { Controlled with the Protectorate of } \\
\text { Bohemia and Moravia, free on the } \\
\text { former 1918-1938 border }\end{array}$ & German (with minor usage of Czech) \\
\hline
\end{tabular}

Source: own elaboration

desire of Sudeten Germans in Czechoslovakia to become part of the German Reich.

The situation got even more complicated in 1938, when many tourist routes on the Czechoslovak side of the border were closed for military purposes, as will be explained later in this paper. These limitations ceased to exist after the annexation of the Sudetes at the end of September 1938, which was hugely celebrated by German-speaking tourist organizations, for example, by erecting a huge swastika on Ještěd.

\section{Border-crossing regimes}

Our paper deals primarily with the period between 1890 and 1940 , when very different border-crossing regimes were in place in the territory studied. The Dresden Convention (1850), joined by Austria in 1859, enabled free border crossing within the states of the German Confederation. This convention remained valid also after the German unification of 1871 (Rychlík 2016). The emperor's regulation of 1865 practically abolished regular border controls, which meant that Austrian citizens had to have their passports only as a matter of formality. This liberal regulation was valid in most of Europe, which changed only at the beginning of World War I in 1914 (Rychlík 2016). The Austro-Hungarian Constitution of 1867 acknowledged the rights of Austro-Hungarian citizens to cross the border and spend time abroad for tourism purposes, to study or for economic activities (Rychlík 2016).

The end of World War I brought along the dissolution of the Austro-Hungarian Empire and the emergence of new states, one of them being Czechoslovakia. The new Czechoslovak authorities abolished uncontrolled border crossing and started to demand regular passports including visa obligations (Wójcik 2014) and temporary permissions - the only exception was the so-called "minor border crossing" which could be used by inhabitants of border areas up to 15 to 20 kilometres from the border. This was very unwelcome by representatives of tourist organizations on both sides of the border - although those on the Czech side could not be so open about this - who strongly disliked the actions of the Czechoslovak authorities who introduced a relatively strict border regime (Wójcik 2014).

There was a shorter period of détente including a temporary lifting of visa obligations at the end of the 1920s. However, after the Nazis gained control in Germany in 1933, the border regime became stricter and visa obligations were reintroduced. This stricter regime - with some exemptions for the sake of minor border crossing for tourist purposes - remained until 1938, as the Sudeten Germans living in Czechoslovakia started to call for annexation by the Third Reich. The tourism mainly on the Czechoslovak side of the border was hugely curbed by measures resulting from the construction of the Czechoslovak defence network of fortresses - starting with a prohibition of photography, and leading to the closure of selected hiking routes.
The old maps analyzed and their interpretation by/ confrontation with border theories

To some extent, in the period studied 1890-1940, the border in the Jizera Mountains territory underwent all four types of existence defined by Martinez. In this section, we firstly analyze the period ending with the founding of Czechoslovakia in 1918. In that period, we expect to find regimes of interdependent and integrated borders. Then we analyze the content of selected maps from the 1918 to 1938 period (Fig. 1), in which we expect to observe the regime of coexistent and alienated borders in 1938 (until the Munich Agreement ). The last, very short part focuses on the period after the Munich Agreement and annexation of the Sudetes by the German Reich until 1940 when the original border ceased to exist.

\section{Old maps 1890-1918}

From 1871 until 1918 borders divided the Austrian monarchy and unified Germany. Both empires became closely associated following the Dual Alliance of 1879, although the Habsburg monarchy was the junior partner. Dependence on the Prussian empire made the German element predominant in the multiethnic Habsburg monarchy. German-speaking populations were split in their identification with Austria and Germany.

As mentioned in the previous part, border crossing was free in this period and this type of border could have been classified as interdependent with elements of an integrated border without joint governance structures for an efficient cross-border administration of the joint territory.

One of the tourist maps depicting the studied territory at the beginning of the 20th century is the first edition of Gustav Adolph's Vom Oybin bis zur Schneekoppe. It was the first edition out of eight altogether, published between 1905 and 1940. The first edition was published in 1905, when the border divided the Austrian Empire and Germany; the last map of 1940 illustrates the "borderless" situation of annexed Sudetenland to the German Reich. We worked with its second edition of 1907.

What is very common for all these maps is a very decent illustration of the border, which can easily be seen. The partial reason may be the fact that a German-speaking population lived on both sides of the border, which kept mutual relations thanks to a non-existent language barrier. Also, the cartographic characters used in the maps - although some are handled imprecisely or in a simplified way compared to current standards - cross the state border; they also capture marked tourist paths that often cross the border, as is well illustrated around the Smrk/Tafelfichte mountain, as there are three (red, green and yellow) tourist routes crossing the border (Fig. 2). The fragment of the currently most popular web portal of tourist maps on the Czech side shows that there is no single tourist map crossing the border now (however on other current tourist maps, there is a marked path crossing the 


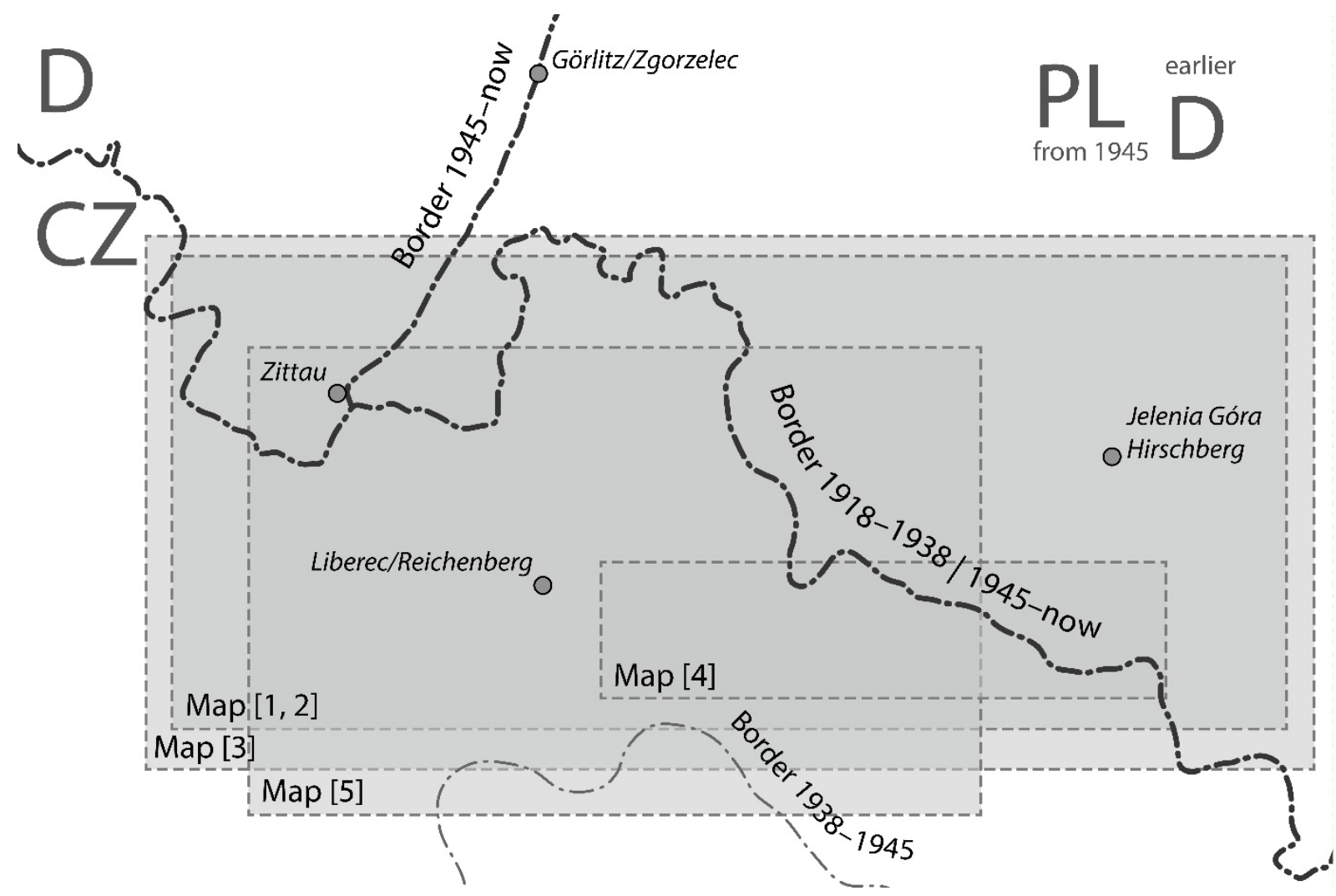

Figure 1. Overview of the geographical coverage of maps used in this paper (for numbering of maps see the list of maps at the end of the paper). Source: own elaboration
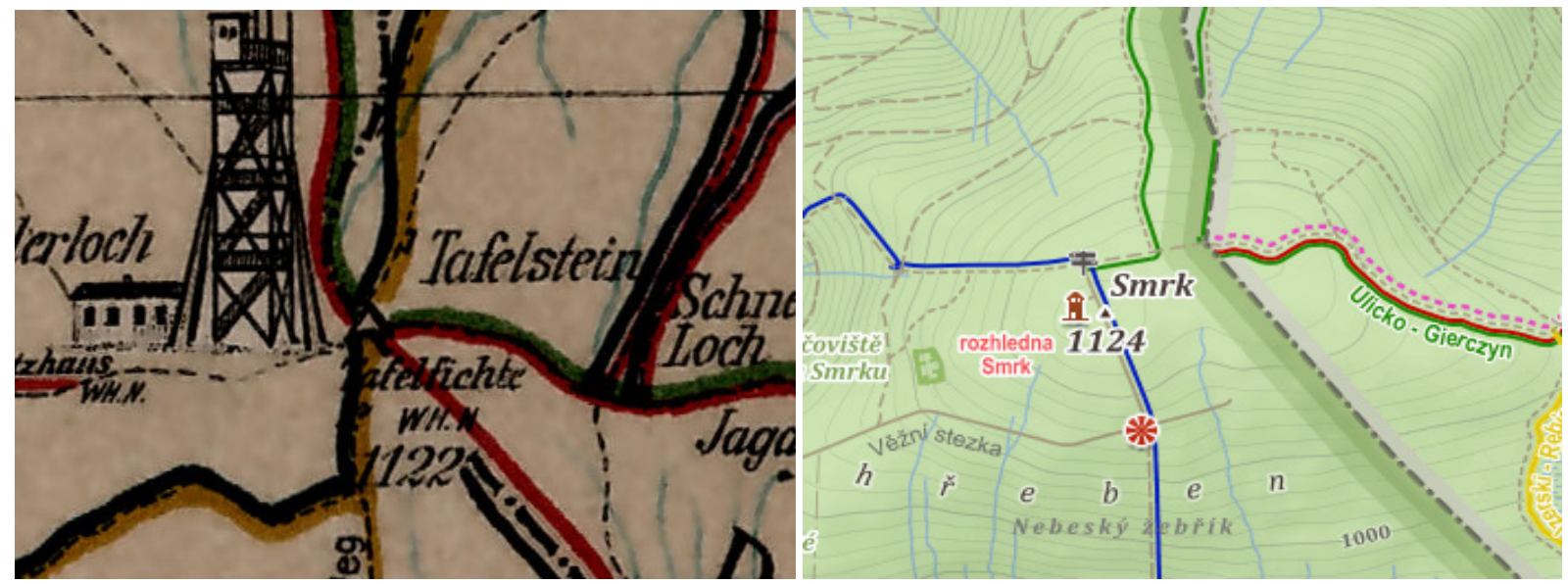

Figure 2. Comparison of the tourist trail on the old map of 1907 (Matouschek) and current tourist map. Source: left - Adolph, C Bengler, A. 1907 (1:100000, author's private collection); right - Seznam.cz 2018.

border - for instance Góry Izerskie by Plan 2017, or Jizerské hory a Frýdlantsko - Edice Klubu Českých turistů, map 20-21, 2015).

\section{Old maps 1918-1938}

The situation at the border changed in 1918, when Czechoslovakia was established and the dominance of the German element in the territory was seriously disrupted. However, most of the population living in the studied territory was German speaking, which was true also for the map creators.
The old maps coming from the 1918-1938 period depicted a completely different political-administrative context - the border was coexistent; at the end of the period it even had some features of alienated borders, as the geopolitical situation of 1938 sharpened dramatically, mainly after the Anschluss of Austria to the German Reich.

Nevertheless, the above-mentioned context of the coexistent border was not reflected in the content of studied maps, at least in most of them made by German-speaking 


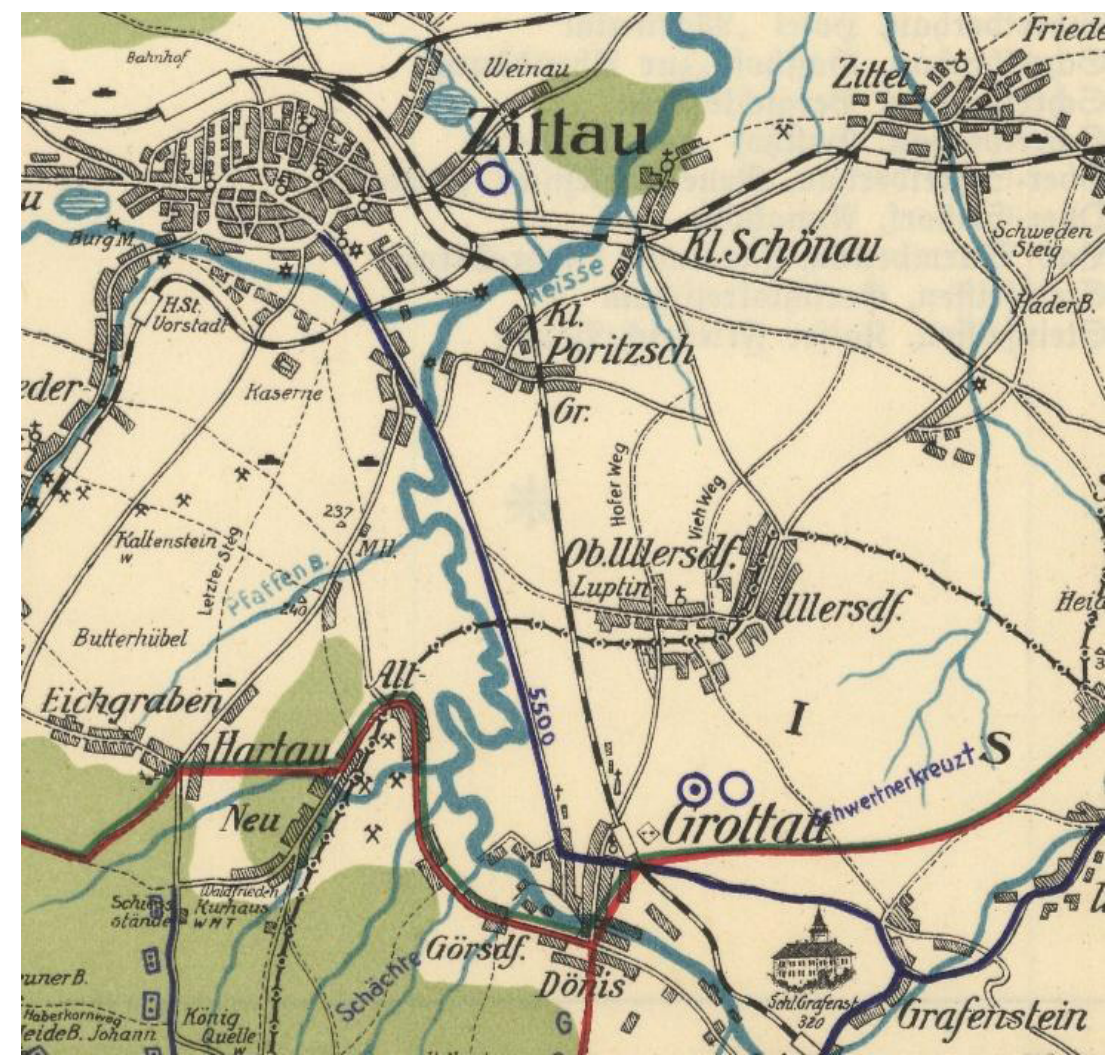

Figure 3. Indication of distance between two places in two countries (on a tourist map). Source: fragment of the map Vom Oybin bis zur Schneekoppe, Gustav Adolph, Gablonz 1927 or 1929 (1:100000, author's private collection).

map authors. For example, when looking at the fourth edition of Adolph's Vom Oybin bis zur Schneekoppe, this old map also tells us the distance between places, irrespective of the side of the border, as evidenced by the distance from (Czech) Hrádek nad Nisou (Grottau) to (German) Zittau (Fig. 3). The frequency of interconnections across the state border suggests that during this period of the first half of the 20th century, the region was relatively interconnected also across the border, even after 1918.

The tourist map Vom Oybin bis zur Schneekoppe (published in Jablonec/Gablonz 1927) gives us further evidence that the border was not a barrier for tourists - the map also contains an indication of the distance between places on different sides of the national borders, as is documented on the example of Hrádek nad Nisou (Grottau) and Zittau.

The outline of the old maps dating from the period between the two world wars clearly documents how the original German population perceived the territory as a functional unit without emphasizing the meaning of borders - this is easily visible on tourist routes crossing the border around Smrk (Tafelfichte) on the map by Josef Matouschek, another important author of maps (Fig. 4). We can talk about a real cross-border tourist region in the sense of Poser's (1939) description.

Most of the analyzed maps were produced after Czechoslovakia was founded in 1918. Yet we should not necessarily blame the German-speaking authors of the maps that they did not want to reflect this political reality. We must underline that the period after 1918 in the Sudetes was characterized by endeavours to find Czech toponyms for the places, which had only German names for centuries.

However, "Czech" geopolitics can be found on the map of the Giant (Krkonoše) and the Jizera Mountains made by the Czech cartographer Jan Havránek during the interwar Czechoslovakia period. It is characterized by the use of Czech local names (absent in Adolph's or Matouschek's maps), and their apparent superiority to German translations, also the depiction of the national border is very visible there (Fig. 5). Except for that difference we should stress the fact that Gustav Adolph used colours to distinguish individual tourist routes, which was very innovative and was not the case in maps made by either Matouschek or Havránek. Moreover, Adolph's use of colours stresses the permeability and openness of the borders for tourism.

\section{Borders do not divide only states}

Another challenge we identified is to find a border on the map that has to be identified "between the lines", which often says something about the region and its internal division far more than the line on the map. A good example of such a border where we need to "read between the lines", is the language border. Havránek's map mainly applies the principle of bilingualism in the north of the Czech part of the depicted area - with a predominant majority German population - but the south-west part of the map, showing the north of the Bohemian Paradise is described only in Czech. The linguistic border is thus visible.

There is also a comparison of the maps of two authors published in German (Fig. 6). While Gustav Adolph on the left is a German with an incomplete knowledge of Czech, Josef Matouschek mastered both languages perfectly. In the map of the same area there are red circles around the wrong names of Czech villages on the map made by Gustav Adolph and the correct - with some minor exceptions - names in Czech on the map of Josef Matouschek. Moreover, the green line roughly labels the linguistic border between the southern Czech and the northern 


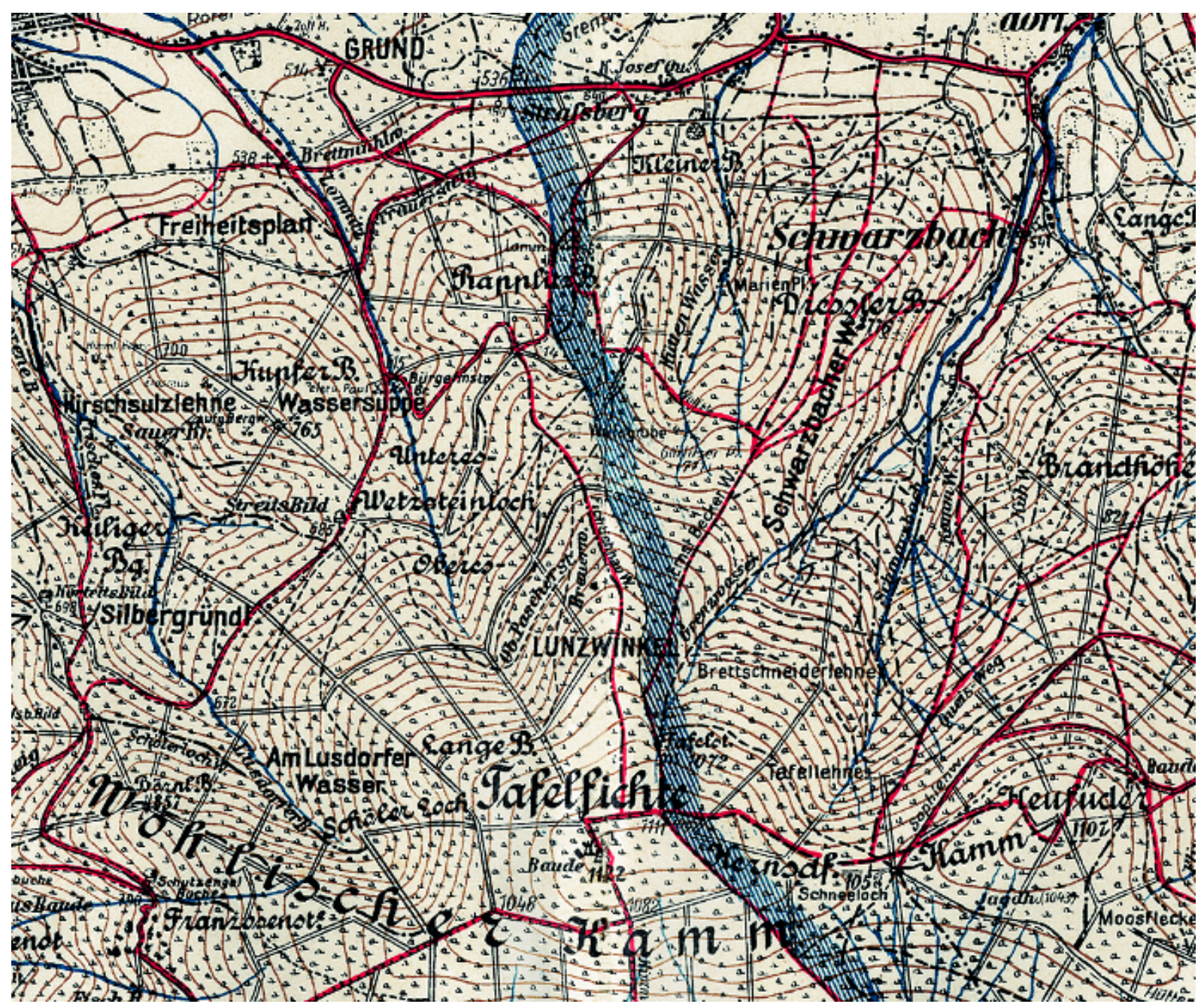

Figure 4. Depiction of tourist marked paths (red lines) frequently crossing the border (blue ribbon). Source: fragment of Josef Matouschek's tourist map Spezialkarte vom Jeschken und Isergebirge, Reichenberg 1927 (1:50000, author's private collection).
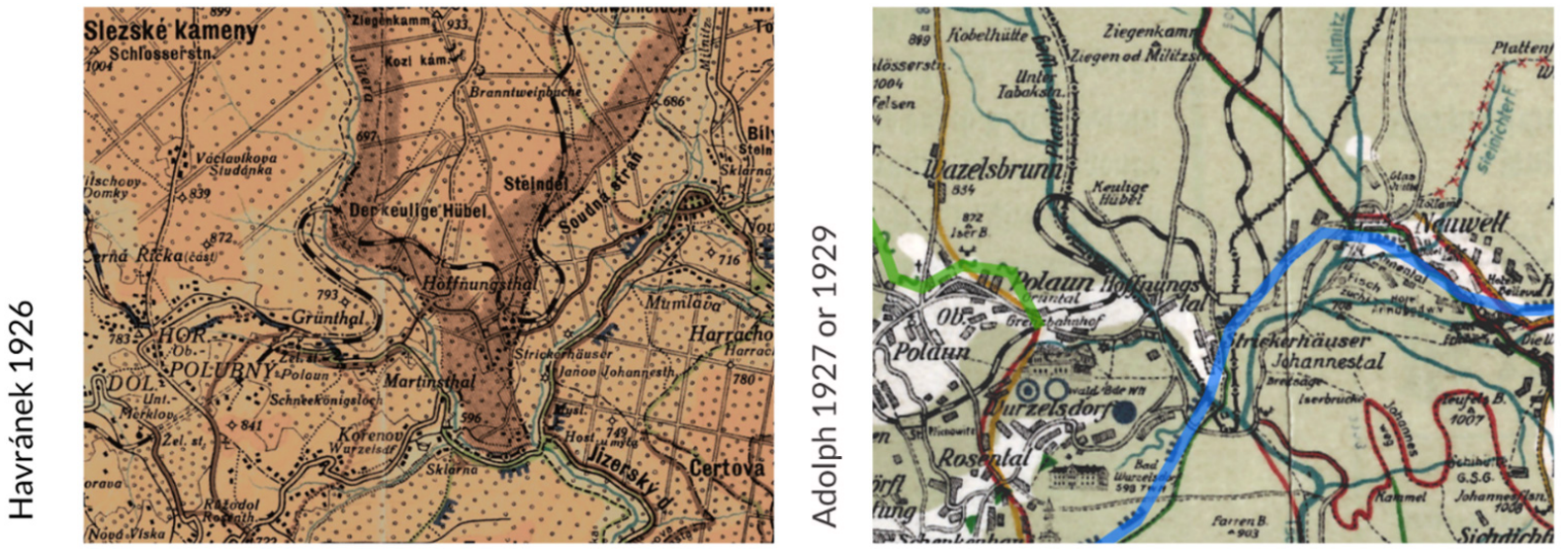

Figure 5. Illustration of the same border territory using Czech and German geopolitics. Source: Havránek 1926 (1:60000), Adolph 1927/1929 (1:100000), (both author's private collection). 


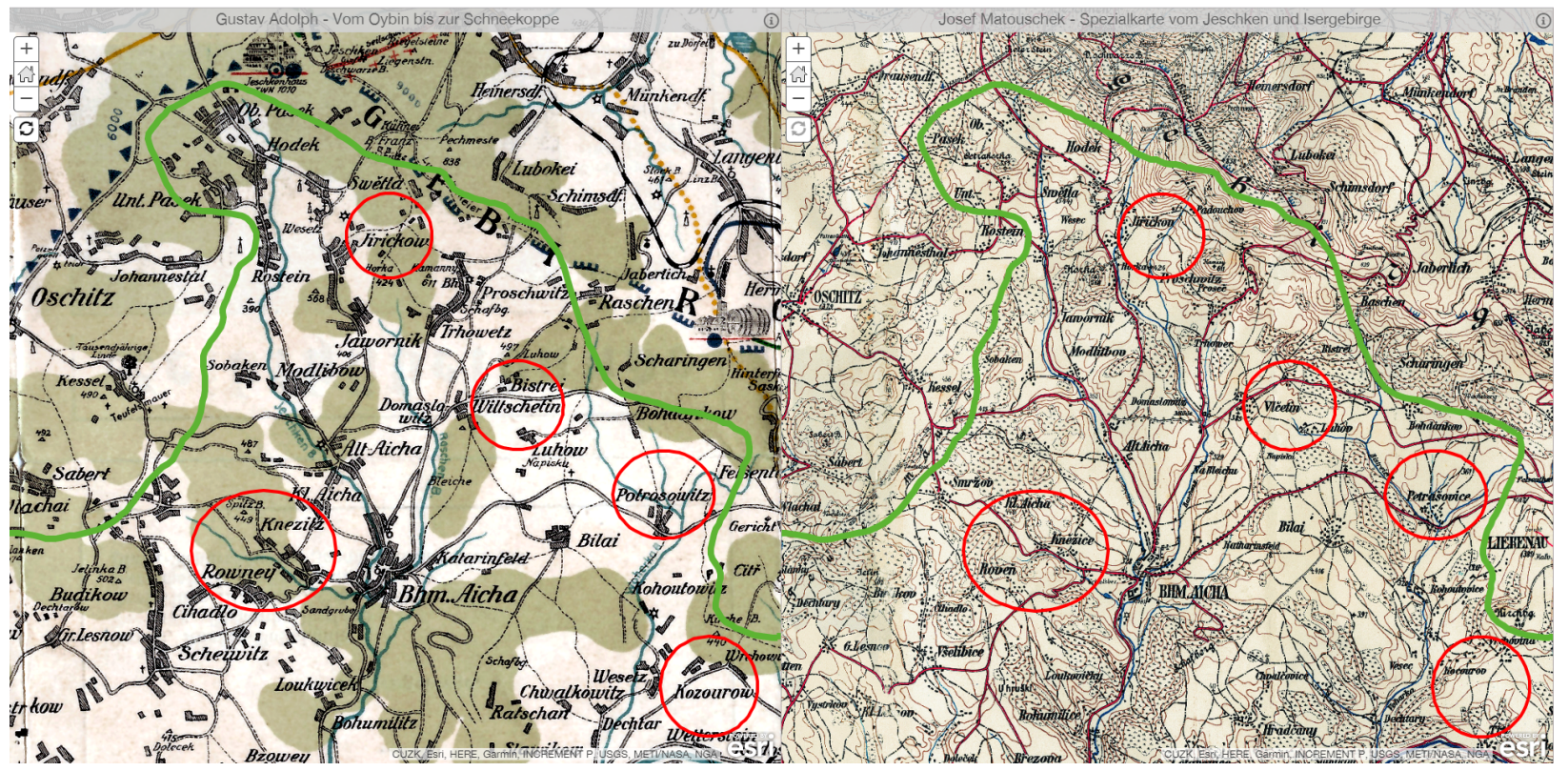

Figure 6. The "invisible" linguistic border and mis-depiction of the names of Czech villages by a cartographer publishing only in German (Gustav Adolph, 1927 or 1929, on the left) and a cartographer familiar with both languages (Josef Matouschek, 1927, on the right). Source: the image is from an interactive web map application developed for the purpose of studying and demonstrating the language boundary in the course of our project (Šmída, Vrbík 2017).

German language communities. The possible explanation could be the origin of Josef Matouschek. He was born into a Czech family (his father's surname was Matoušek), but later on he was raised and educated in German schools and environments.

\section{Old maps (October) 1938-1940}

The Munich Agreement of September 1938 brought the annexation of the Sudetes by the Third Reich, followed by the creation of the Protectorate in March 1939 - this entity was controlled by Germans with a certain level of autonomy still in the hands of a Czech administration during World War II. The former Czechoslovak-German border thus ceased to exist. The situation was depicted on the seventh edition of the Vom Oybin bis Schneekoppe map of 1939 (Fig. 7). The year of publication was changed in the legend, where the original border dividing Czechoslovakia and Germany before was depicted as "Alte Reichsgrenze" - old border of the empire (Fig. 4). We do not know why the non-existent border - an example of Jańczak's (2014) "Phantom border" - was actually put on that map. Similarly, as in the case of most examples of old tourist maps, we cannot rely on the documented methods of the work of the author. Hence we have been speculating about the motives of the authors of these maps to illustrate and interpret a certain topic. We could speculate that the author wanted to convey an implicit message by depicting a border that no longer existed at that time. Alternatively, we could also speculate that he merely did not want to discontinue the previous six editions. Alternatively, the reasons could have been of a technical nature - the map could have been already in print or major modifications were not technically possible. The modification of the legend could have been a compromise which caused no problems for the publisher.

\section{Discussion and conclusions}

One of our research goals was an analysis of maps of the border area created mainly for tourists. We wanted to point out their geopolitical importance, as they can serve also to understand the political and maybe also the geopolitical organization of neighbouring countries. In our paper, we came to multiple conclusions, which partly confirmed the statements highlighted in the theoretical part, but just to a limited extent.

State borders are mostly depicted very legibly in current maps or in atlases, and can be eye-catching. Hence we started our analysis with the depiction of national borders in old maps. We based our work on an analysis of Gustav Adolph's series of eight tourist maps, Vom Oybin bis zur Schneekoppe, published between 1905 and 1940. The first edition was published in 1905, when the border divided the Austrian Empire and Germany, the last map of 1940 illustrates the "borderless" situation of Sudetenland annexed to the German Reich. What is very common for all of these maps is the very decent illustration of the border, which can easily be seen. A partial reason may be the fact that German-speaking populations lived on both sides of the border, which kept mutual relations possible, thanks to a non-existent language barrier. The cartographic characters used in the maps - although some are handled imprecisely or in a simplified way in comparison to current standards - cross the state border. They also capture marked tourist paths that often cross the border, as well as tell us distances between places, irrespective of the side of the border.

The frequency of interconnections across the state border suggests that in the first half of the 20th century, the region was also relatively interconnected across the border. The question is whether this is due to the German nationality of the author of the map. The other possible answer might be in the lively relationships between the populations of both sides of the border, which in fact called for a higher level of interdependence and relationships with their fellows on the other side.

The old tourist maps can be used in the study of the political organization of the neighbouring regions through a more detailed analysis of the accentuation of the boundaries, as the graphic elements for its representation correspond to its distinctiveness and significance attributed by the cartographer of the map as a 


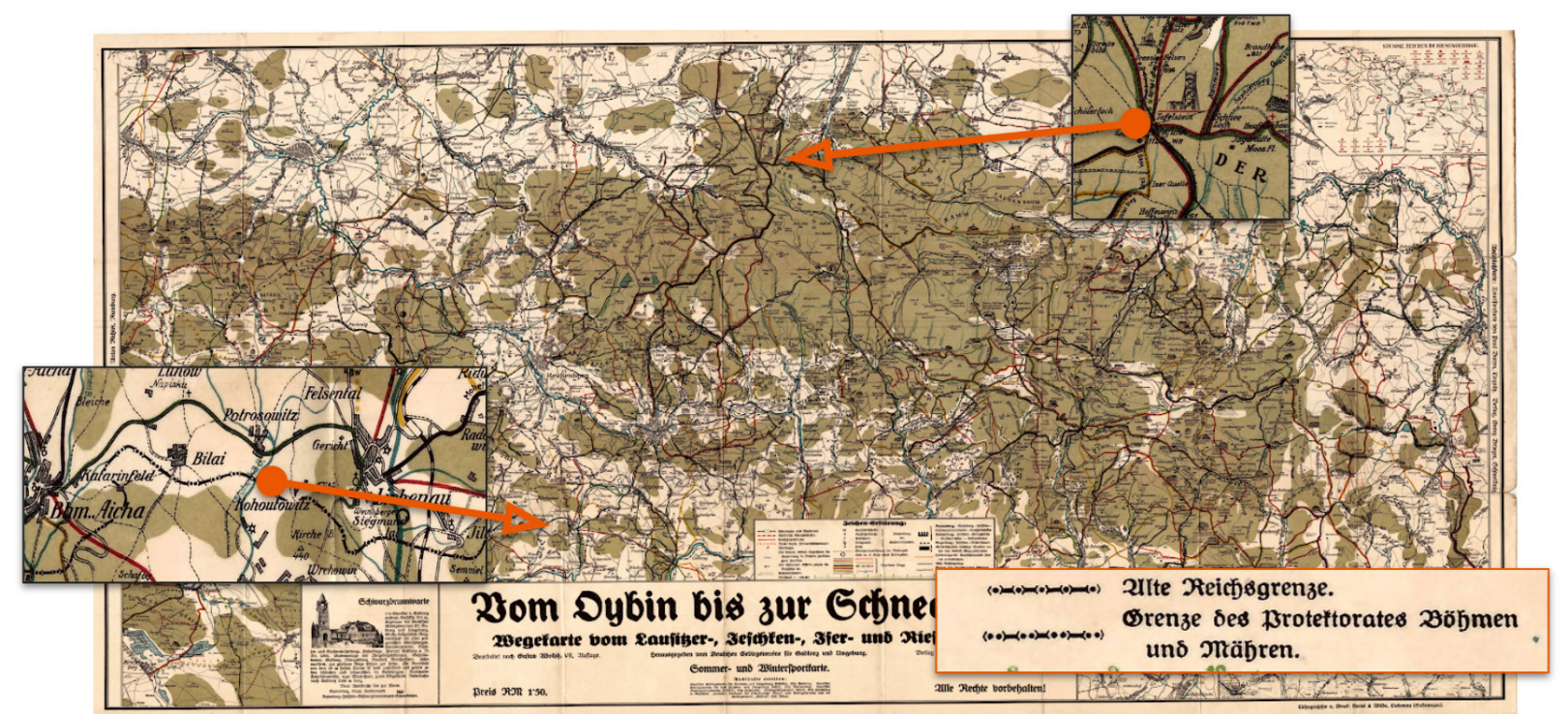

Figure 7. The example of a map with confusing political borders (Vom Oybin bis zur Schneekoppe map of 1939, see legend). Source: own elaboration based on Adolph 1939 (1:100000, author's private collection).

barrier separating the adjacent regions. And more importantly, the maps studied revealed the frequency and ways of keeping tourist trails as important components of the tourist infrastructure across national borders. Tourist paths crossing the border can be interpreted as evidence of its permeability, perhaps despite the official declarations on the role of the border and its barrier functions. Tourist routes reflected the needs of the inhabitants and visitors of the region, who did not want to perceive the border as a barrier for their movement through the landscape. The border crossing for tourists did not cease to exist even at the time of the foundation of Czechoslovakia in 1918, but it was the subject of constraints. Border crossing collapsed in 1938, when the general Czechoslovak mobilization, preceded by the use of the borderland for the construction of defence lines of fortresses, curbed it dramatically, a process reaching back to the years after Hitler gained control in Germany in 1933.

Old tourist maps can thus sometimes render a source of information that demonstrates the identification of users (residents and visitors) with the border region and the nature of cross-border movement. They may also be inconsistent with official standards and may be the reason why it is not easy to classify their boundaries according to Martinez's methodology which was the case for the disproportion between the relatively interconnected border region of Jizera Mountains in Matouschek's or Adolph's maps and the de facto "just" coexistent regime at the borders in the 1918-1938 period.

We also wanted to ascertain and describe how the borders between neighbouring states were illustrated in these old maps. There is neither a simple nor a single answer to this question. However, we can say that the answer is highly linked to the background of the map creator. German-speaking map authors preferred to illustrate the borders in a decent way, they did not let the borders dominate the territory where the German language was the lingua franca on both sides since the Middle Ages. It should be remembered that the German-speaking population living in the Sudeten mostly declined to become part of Czechoslovakia after its creation in 1918 - Germans even declared the autonomous province Deutschböhmen and wanted it to become part of Austria. The low level of their self- identification with Czechoslovakia was also expressed in their maps, which - as mentioned - tended to illustrate their ambition for frontierization - they understood the illustrated territory as a single space.

Czech authors tended to underline the boundarization processes in their maps. That is understandable - the creation of Czechoslovakia brought along the idea of "Czechoslovak statehood/dominant nationality", which needed to be made visible also in areas with a non-Czech(oslovak)-speaking population who were forced to become part of Czechoslovakia after its creation in 1918. However, as most of the maps studied were created by German-speaking authors, we shall be very careful about any possible generalization at this point. The Czech authors of maps we were able to gather for our research tended to illustrate the borders as a boundary separating state structures. As the German-speaking authors of maps tended to de-legitimize the borders in the 1918-1938 period, the Czech ones did the opposite: illustrated them as a separator from the outside and a binder of the inside, and drew sharp lines that marked the limits of authority and ownership.

As mentioned, we failed to verify whether Martinez's (1994) border typology based upon the openness of borders and identifying four main types of borders can be entirely applied when studying old maps. We came to the conclusion that this can be done only partially. The maps studied - coming from the 18901940 period - could have been classified into all four categories proposed by Martinez. Maps of the 1890-1918 interdependent period appear to be really interdependent (practically integrated) and offer many cross-border connections - this would confirm Martinez's typology. However, most of the 1918-1938 maps illustrate the coexistent period, which is depicted in a very interdependent/integrated way on most of the maps studied. As was repeatedly stated in earlier paragraphs, German-speaking authors tended to depict the borders in a much "lighter/softer" way than Czech ones. This can lead us to the conclusion that the (civic) society living in the border region in 1918-1938 made all the effort towards de-bordering. The integrated borders showed the territory in the dark times of the beginning of World War II and only one studied map covered that period - the seventh edition of 
MISCELLANEA GEOGRAPHICA - REGIONAL STUDIES ON DEVELOPMENT

Vol. 23 • No. 4 • 2019 • pp. 199-209 • ISSN: 2084-6118 • DOI: 10.2478/mgrsd-2019-0021

Table 2. Border typology, their characteristics and appropriate old maps

\begin{tabular}{|c|c|c|c|}
\hline Type of border & Characteristics & $\begin{array}{l}\text { Maps corresponding to the individual } \\
\text { border types }\end{array}$ & Historical period \\
\hline Alienated & $\begin{array}{l}\text { - Rigidly divide two countries } \\
\text { - Militarized border areas } \\
\text { - Minimal transborder traffic }\end{array}$ & & In 1938 \\
\hline Coexistent & $\begin{array}{l}\text { - Borders filter transborder flows } \\
\text { - States maintain contact and } \\
\text { cooperate } \\
\text { - Most land borders in the world }\end{array}$ & $\begin{array}{c}\text { Adolph, G } 1927 \text { or 1929, Vom Oybin bis } \\
\text { zur Schneekoppe } \\
\text { Havránek, J 1926, Krkonoše a Hory } \\
\text { Jizerské } \\
\text { Matouschek, J 1927, Spezialkarte vom } \\
\text { Jeschken und Isergebirge }\end{array}$ & 1918-1938 \\
\hline Inter-dependent & $\begin{array}{l}\text { Countries have achieved a high } \\
\text { degree of political rapprochement } \\
\text { and mutual trust } \\
\text { - Visa regime is lifted, border areas } \\
\text { are fully demilitarized }\end{array}$ & $\begin{array}{c}\text { Adolph, G, Bengler, A 1907, Vom Oybin } \\
\text { bis zur Schneekoppe }\end{array}$ & Until 1918 \\
\hline Integrated & $\begin{array}{l}\text { - Completely open border } \\
\text { - Cross-border agglomerations and } \\
\text { region with governance structures } \\
\text { created }\end{array}$ & $\begin{array}{l}\text { Mapy.cz (Seznam.cz) } \\
\text { Adolph, G 1939, Vom Oybin bis zur } \\
\text { Schneekoppe }\end{array}$ & $\begin{array}{c}\text { After Munich Agreement } \\
\text { of } 1938 \text { - May } 1945 \\
\text { 2007- now }\end{array}$ \\
\hline
\end{tabular}

Source: own elaboration

Adolph's Vom Jeschken bis zur Schneekoppe. It did not change much from their previous edition, just pointed at a phantom border - the former Czechoslovak-German one. Direct correlations between Martinez's typology and tourist maps fail also when confronting current tourist maps of the Jizera Mountains (using the most popular portal mapy.cz) depicting integrated Schengen borders, as the number of cross-border tourism trails depicted on mapy.cz is significantly lower that it was in the case of the old maps studied.

The maps studied also offered us other possible research topics, as they offered many examples of the depiction of invisible or mental borders and the application of more languages and toponyms; we could also observe the development of the toponyms in the territory of our interest. This confirmed our expectations that the matter deserves further and more profound attention and we would like to continue our work in that direction. However, we must repeat that we failed to identify a direct link between Martinez's typology and old tourist maps. We think that we could have been more successful if we had studied other maps, but this will be the subject of another research project.

On the other hand, we can say that the study of old tourist maps confirmed our second hypothesis on cross-border tourist regions. Most of the old maps studied depicted the territory of the Jizera Mountains as a cross-border region with many bordercrossing elements, mainly tourist routes. Tourism in the Jizera Mountains - starting much before 1890 and at least until the end of studied period - helped to create distinctive cross-border tourist regions.

\section{Acknowledgements}

The authors would like to thank Izabela Karsznia, all anonymous reviewers for their feedback and comments and language editor with the English proofreading.

\section{References}

Anderson, M 1996, Frontiers: Territory and state formation in the Modern World, Polity Press; Blackwell Publishers. Cambridge-Oxford.

Böhm, H 2019, 'Cross-border co-operation from the perspectives of political sciences' in Transdisciplinary Discourses on Cross-Border Cooperation in Europe, ed J Beck, Peter Lang, Brussels, pp. 59-82.

Brunet-Jailly, E 2005, 'Theorizing borders: An interdisciplinary perspective', Geopolitics, vol. 10, no. 4, pp. 633-649.

Burcher, T 1996, 'The Sudeten German question and CzechoslovakGerman relations since 1989', Whitehall Papers, vol. 34, no.1, The Royal United Services Institute, London.

Custred, G 2011, 'The linguistic consequences of boundaries, borderlands and frontiers', Journal of Borderland Studies, vol. 26 , no. 3, pp. 265-278.

Czetwertyński-Sytnik, L, Koziol, E \& Mazurski, KR 2000. 'Settlement and sustainability in the Polish Sudetes'. GeoJournal, vol. 50, no. 2-3, pp. 273-284.

Dołzbłasz, S 2017. 'From divided to shared spaces: Transborder tourism in the Polish-Czech borderlands' in Tourism and geopolitics: issues and concepts from Central and Eastern Europe, ed. Hall, D, CABI, Wallingford, Boston, pp. 163-177.

Dołzbłasz, S \& Raczyk, A 2010, 'The role of the integrating factor in the shaping of transborder co-operation: The case of Poland, Quaestiones Geographicae, vol. 29, no. 4, pp. 65-73.

Van Houtum, H 1999, 'Internationalisation and mental borders', Tijdschrift voor Economische en Sociale Geografie, vol. 90, no. 3, pp. 329-335. 
Jańczak, J 2014, 'Borders and border dimensions in Europe. Between frontierisation and boundarisation', Public Policy and Economic Development, vol. 2, pp. 7-18.

Kolejka, J, Żyszkowska, W, Batelková, K, Ciok, S, Dołzbłasz, S, Kirchner, K, Krejčí, T, Raczyk, A, Spallek, W \& Zapletalová, J 2015, 'Permeability of Czech-Polish border using by selected criteria', Geographia Technica, vol. 10, no. 1, pp. 51-65.

Kolosov, VV 2015, 'Theoretical approaches to border studies' in Introduction to Border Studies, eds SV Sevastianov, J Laine \& AA Kireev, Far Eastern University, Vladivostok, pp. 33-61.

Kreisel, W 2004, 'Geography of leisure and tourism research in the German-speaking world: Three pillars to progress', Tourism Geographies, vol. 6, no. 2, pp. 163-185.

Kristof, L 1959, 'The nature of frontiers and boundaries', Annals of the Association of American Geographers, vol. 49, no. 3, pp. 269-282.

Martinez, OJ 1994, Border people: Life and society in the U.S. -Mexico borderlands, Tucson, The University of Arizona Press.

Miszewska, B 1994, 'Przemiany ludnościowe na Dolnym Śląsku po Il wojnie światowej' ['Population changes in Lower Silesia after World War II']. in Przemiany ludnościowo-osadnicze $i$ spoleczno-gospodarcze na Dolnym Śląsku po II wojnie światowej, ed. J Loboda, Studia Geograficzne, vol. LXI, Acta Univ. Wratislaviensis, Wrocław, pp. 51-69.

Murgaš, F 2019, 'Can Easterlin's paradox be applied to the development of satisfaction with life or does the explanation lie in cultural geographical characteristics?' Geografický časopis, vol. 71, no. 1, pp. 3-14.

O'Dowd, L \& Wilson, T 2002, 'Frontiers of sovereignty in the new Europe', in Borders of Europe, ed. N Alkan, Bonn, Zentrum für Europäische Integrationsforschung, pp. 7-30.

Poser, H 1939, 'Geographische Studien über den Fremdenverkehr in Riesengebirge: Ein Beitrag zur Geographischen Betrachung des Fremdenverkehrs' ['Geographical studies on tourism in Giant Mountains: contribution on geographical approach of tourism'], Abhandlungen der Geselschaft d. Wissenschaften zu Göttingen, vol. 20, no. 3.

Potocki, J 2004, Rozwój zagospodarowania turystycznego Sudetów od połowy XIX wieku do II wojny światowej [Development of touristic use of Sudetes from mid 19th century to World War II], Wydawnictwo Turystyczne Plan, Jelenia Góra.

Rychlik, J 2016, 'Překračování hranic a emigrace v Československu a východní Evropě ve 20. století' ['Border crossing and emigration in Czechoslovakia and Eastern Europe in $20^{\text {th }}$ century'], Securitas Imperii, vol. 29, no. 2, pp. $10-72$.

Stryjakiewicz, T 1998, 'The changing role of border zones in the transforming economies of East-Central Europe: The case of Poland', GeoJournal, vol. 44, no. 3, pp. 203-213.

Wójcik, J 2014, 'Granica państwowa w turystycznej przestrzeni Sudetów w latach 30. XX wieku w świetle niemieckojęzycznej prasy turystycznej' ['National border in tourism space of Sudetes in 1930's in the light of German-written tourism press'], in Społeczeństwo $w$ przestrzeni gór w XIX i XX wieku, eds. T Przerwa, P Ziomek, K Manikowski \& J Wójcik, Wyd. Studio ERGIEBE, Wrocław - Bielsko Biała, pp. 84-96.

\section{List of Maps}

[1] Adolph, G \& Bengler, A 1907, Vom Oybin bis zur Schneekoppe. Wegekarte vom Jeschken- und Isergebirge mit den angrenzenden Teilen des Lausitzer- und Riesengebirges [From Oybin to the Schneekoppe. Hiking maps of Ještěd and Jizera Mountain and adjacent parts of Lužice and Giant Mountains]. [1: 100 000], H. Rösslers Buchhandlung, Gablonz a.N., vol. 2, $990 \times 520 \mathrm{~mm}$.

[2] Adolph, G 1927 (or 1929), Vom Oybin bis zur Schneekoppe: Wegekarte vom Lausitzer-Jeschken-Iser und Riesengebirge [From Oybin to the Schneekoppe. Hiking maps of Lužice and Ještěd-Jizera Mountain and Giant Mountains]. [1:100 000], vol. 6, $990 \times 520 \mathrm{~mm}$.

[3] Adolph, G 1939, Vom Oybin bis zur Schneekoppe: Wegekarte vom Lausitzer-Jeschken-Iser und Riesengebirge [From Oybin to the Schneekoppe. Hiking maps of Lužice and Ještěd-Jizera Mountain and Giant Mountains]. [1: 100 000], vol. 7, $1032 \times 499 \mathrm{~mm}$.

[4] Havránek, J 1926, Krkonoše a Hory Jizerské [Jizera Mountain and Giant Mountains]. [1 : 60 000]. 890 x 455 mm. Nakl. Ed. Fastr, Louny.

[5] Matouschek, J 1927, Spezialkarte vom Jeschken und Isergebirge [Special map of Ještěd and Jizera Mountain]. [1 : 50 000]. $1270 \times 720$ mm. Deutscher Gebirgsverein für das Jeschken und Isergebirge, Reichenberg/Liberec.

[6] Seznam.cz 2018, Mapy.cz. Available from: <https://mapy. cz/turisticka? $x=15.2707915 \& \quad y=50.8886763 \& z=15>$. $\quad[20$ August 2018].

[7] Šmída, J \& Vrbík, D 2017, "Invisible” linguistic border on Ještěd Ridge - Interpretation of toponym. Technical University of Liberec. Available from: <https://goo.gl/ wDtKJp>. [20 August 2018]. 